\title{
Tips untuk Agribisnis Pertanian di Era Revolusi Indutri 4.0
}

\author{
AMIRIL MUMININ \\ Universitas Nahdlatul Ulama Sidoarjo
}

\section{PENGANTAR}

Gagasan memulai bercocok tanam dari awal memang menakutkan, apalagi agribisnis pertanian. Jutaan hingga milyaran rupiah di real estat tanah pertanian serta dalam peralatan. Belum lagi semua uang dalam input seperti benih dan pupuk. Semua untuk bertaruh pada fakta bahwa bumi nusantara akan memungkinkan Anda untuk menghasilkan tanaman yang akan dibeli seseorang.

Masyarakat membutuhkan kewirausahaan (Setyawati, Purnomo, Irawan, Tamyiz, \& Sutiksno, 2018). Manajemen adalah proses mengarahkan atau menjalankan bisnis, serta. sekelompok manajer atau direktur (Purnomo, Putri, \& Rosyidah, 2017). Jika Anda memulai tanpa setumpuk uang atau tanah pertanian di keluarga Anda, apakah itu mungkin?. Berikut beberapa tips untuk memulai wirausaha pertanian agribisnis di era revolusi industri 4.0.

\section{MERENCANAKAN DAN MENDOKUMENTASIKAN}

Jika Anda tidak memiliki catatan panjang dalam menjalankan bisnis pertanian, sangat penting untuk mulai mendokumentasikan keuangan Anda hingga pengeluaran terkecil dan penerimaan pendapatan. Dokumentasi tersebut sangat penting untuk rencana bisnis pertanian yang solid, yang pada gilirannya penting untuk menumbuhkan operasi setelah Anda memulai. Dan, berpegang teguh pada rencana bisnis itu; mendapatkan operasi dari tanah bukan saatnya untuk jenis manajemen "kursi-of-the-celana" (Weaver, 2019).

\section{BACA}

Bukan kebetulan bahwa banyak orang yang paling sukses adalah pembaca. Pebisnis pertanian sukses telah dapat mempelajari prinsip-prinsip kepemimpinan, konsep keuangan / akuntansi, struktur operasional, dan banyak lagi dari menyelam ke dalam buku dan menerapkan apa yang dia pelajari ke bisnisnya (Hammerich, 2018). Dengan kelapang kita bisa membaca lingkungan misal kunjungan etnobotani. Pendekatan etnobotani berguna untuk mencegah hilangnya pengetahuan tanaman medis karena memiliki peran penting dalam menjaga kesehatan masyarakat (Zikri et al., 2018). 


\section{JANGAN LUPA PERAWATAN DIRI}

Ini seringkali bisa menjadi hal yang tabu dalam industri pertanian, namun menjaga kesejahteraan Anda sendiri sangat penting. Tidak apa-apa untuk mengatakan Anda tidak apa-apa dan tidak seorang pun boleh merasa terlalu bangga untuk meminta bantuan. Pebisnis pertanian sukses menyarankan agar semua orang yang terlibat dalam bisnis pertanian Anda merasa bahwa mereka dapat: Luangkan 'waktu istirahat', Ambil liburan, Mengembangkan dan mengejar minat di luar pertanian, dan Kembangkan lingkaran sosial yang bervariasi (McLean, 2019).

\section{MENYIMPAN CATATAN}

Catatan bisnis pertanian dapat disimpan secara manual, di internet atau terkomputerisasi pada platform seperti spreadsheet. Catatan memudahkan untuk menyimpan dan mengambil informasi yang diperlukan untuk menyiapkan laporan keuangan. Ketika datang untuk segala jenis usaha, berjabat tangan dengan seorang pria biasanya tidak cukup. Pencatatan berfungsi sebagai cara hukum untuk membangun transaksi bisnis antara para pihak. Motivasi pribadi juga dapat ditingkatkan dengan mencatat dan memantau kemajuan. Ini membantu memastikan apakah investasi menguntungkan, perlu perbaikan, atau apakah sudah saatnya mencabutnya (Ekong, 2019).

\section{TEMUKAN TANAH YANG TEPAT}

Setelah mengetahui apa yang akan ditanami, Anda harus memutuskan apakah akan membeli tanah atau menyewanya. Jika Anda membeli tanah, Anda akan memiliki kendali penuh atas penggunaannya, tetapi Anda juga akan menanggung risiko keuangan untuk kesuksesan perusahaan Anda. Ini adalah salah satu alasan utama penyewaan tanah adalah pilihan populer bagi banyak petani baru. Ini meminimalkan risiko keuangan dan membutuhkan modal berkurang sejak awal. Jika Anda tertarik untuk menyewa tanah pertanian, pertimbangkan untuk mencari orang yang memiliki tanah, tetapi yang tidak melakukan apa-apa dengannya. Banyak pemilik tanah dengan tanah yang subur tidak menggunakannya untuk pertanian tetapi dapat mengambil manfaat darinya baik dalam bentuk kredit pajak yang terkait dengan penggunaan pertanian atau untuk meningkatkan nilai properti (Landau, 2019).

\section{Membeli Tanahmu Sendiri}

Membeli tanah pertanian, atau tanah pertanian, bukan untuk semua orang yang belajar cara memulai pertanian, tetapi jika Anda merasa itu pilihan terbaik bagi Anda, ada beberapa cara praktis untuk mencari tahu di mana memulai pencarian Anda. Mempersempit area pencarian Anda dengan hanya mempertimbangkan areaarea yang memiliki pilihan pekerjaan di luar pertanian (atau pasar untuk produk pertanian Anda dan layanan dukungan pertanian yang diperlukan). "Sangat 
membantu untuk mendapatkan peta jalan kertas kuno dan menggambar dua lingkaran: satu dengan pekerjaan di luar pertanian di tengah dan jari-jari sejauh jarak yang ingin Anda tempuh, yang lain dengan basis pelanggan Anda di tengah dan radius sejauh jarak yang ingin Anda tempuh ke pasar, "Di mana lingkaran tumpang tindih adalah di mana kamu harus mencari tanah."

\section{Hal yang perlu dipertimbangkan ketika mencari tanah}

Sebelum Anda menemukan orang yang tepat untuk membantu Anda membeli tanah, ada baiknya membiasakan diri dengan hal-hal yang perlu Anda pertimbangkan saat menjelajah (Landau, 2019).

\section{Paling tidak ini termasuk:}

Kedekatan Anda dengan pasar. Pertimbangkan ke mana Anda akan menjual produk Anda, atau bagaimana Anda akan mencapai saluran penjualan. Jika jaraknya ratusan mil, Anda akan berjuang lebih keras untuk sampai ke pasar. Sering kali paling mudah untuk memulai lokal dan pergi dari sana. Anda mungkin sudah menyelesaikan riset pasar Anda sekarang dan seharusnya sudah memiliki gagasan yang cukup bagus tentang di mana pasar Anda berada. Gunakan diagram di atas untuk membantu Anda menentukan area "kanan" untuk memulai pencarian tanah Anda.

\section{Akses ke air:}

Penting untuk memastikan Anda memiliki persediaan air yang stabil, jadi pastikan untuk mengajukan banyak pertanyaan dan pertimbangkan semua pilihan Anda. Bagaimana Anda menyediakan air untuk tanaman, hewan, dan kebutuhan pemrosesan bisnis Anda?

Jika tanah yang Anda beli memiliki sumur, selalu baik untuk mendapatkan informasi tentang sumur, seperti jenis, kedalaman, keluaran, dan usia. Anda mungkin juga menginginkan laporan kualitas air. Jika properti terhubung ke pasokan air kota, mengetahui harga layanan juga dapat membantu Anda menentukan kelayakan perusahaan tertentu. Jika Anda harus membayar per galon atau kaki kubik, Anda dapat mempertimbangkan kembali membudidayakan ikan trout dan mencoba susu unta sebagai gantinya.

\section{Kualitas tanah:}

Seperti halnya air, tanah berkualitas tinggi adalah keharusan bagi sebagian besar petani. Tanyakan pemilik saat ini untuk hasil tes tanah. Tes tanah sering tersedia melalui layanan penyuluhan lokal dan penjual harus mengharapkan untuk memberikan hasil tes. Pengujian tanah dapat menjadi prediktor penting dari kapasitas dan biaya produksi. Prediksi akurat kebutuhan pupuk untuk tanaman tertentu dapat dibuat berdasarkan hasil pengujian, yang terurai menjadi nilai dolar aktual ketika tumbuh. Untuk ternak, tanah yang berbeda bahkan dapat mempengaruhi pertumbuhan dan kesehatan, kadang-kadang membutuhkan suplemen. 


\section{Sarana dan prasarana:}

Tergantung pada jenis pertanian yang Anda inginkan, Anda mungkin juga membutuhkan bangunan luar yang berbeda. Sebuah kios hasil bumi atau toko pertanian mungkin memerlukan investasi di muka. Bagaimana dengan ternak Anda? Apakah tanah itu termasuk tempat berlindung bagi hewan yang Anda rencanakan untuk pemeliharaan? Bagaimana dengan fasilitas pemrosesan? Berbagai tanaman dan produk hewani akan membutuhkan fasilitas pemrosesan dan penyimpanan yang berbeda. Pastikan juga memikirkan hal-hal yang tidak terkait langsung dengan properti. Jenis transportasi dan jalan apa yang tersedia ke dan dari daerah tempat Anda bertani? Meskipun Anda ingin keseimbangan akses yang mudah dan kedekatan dengan pasar penjualan Anda, perlu diingat bahwa jalan yang sibuk dapat berdampak pada ternak, tanah, dan kualitas air.

\section{Tetangga:}

Ini bisa menjadi sumber yang bagus, atau halangan besar, tergantung. Apakah mereka menghasilkan barang pertanian? Apa praktik produksi mereka? Apakah mereka kompatibel dengan milik Anda? Jika Anda berencana untuk memulai pertanian sayuran organik, tetapi tetangga Anda menyemprot perkebunan pohon Natal mereka dengan pestisida dan herbisida yang keras beberapa kali dalam setahun, ini dapat secara dramatis mempengaruhi kesuksesan Anda. Mengoperasikan operasi pertanian yang sukses akan terjadi jauh lebih mudah jika Anda memiliki hubungan yang baik dengan tetangga Anda. Temui tetangga Anda. Tawarkan untuk membantu tetangga Anda. Jadilah tetangga yang baik. Pertanian dulu jauh lebih banyak tentang masyarakat. Jauh lebih mudah untuk sukses sebagai petani jika Anda mendapat sedikit saja dukungan dari komunitas Anda.

\section{PEMASARAN AGRIBISNI ONLINE}

Teknologi juga meningkatkan pemasaran agribisnis. Pentingnya pemasaran agro dalam pertanian adalah salah satu yang sering diabaikan. Rencana pemasaran akan membantu Anda mengenali saluran pemasaran terbaik dan strategi paling efektif untuk agrobisnis Anda. Munculnya internet telah meningkatkan perencanaan dan distribusi hasil pertanian sedemikian rupa untuk memuaskan petani, produsen, dan konsumen. Pemasaran Internet tidak hanya memudahkan menjangkau pasar yang luas (tanpa batasan lokasi), tetapi juga menciptakan kenyamanan bagi konsumen. Situs web dapat dibuat untuk memudahkan pelanggan mendapatkan informasi yang diperlukan dan layanan E-commerce dapat disesuaikan untuk pelanggan yang ingin melakukan pemesanan. Petani menjual produk mereka. Internet juga memudahkan untuk mempersonalisasikan penawaran dengan menggunakan analitik pelanggan untuk menentukan penawaran apa yang paling cocok (Ekong, 2019). Teknologi juga berkembang ke budidaya tanaman misal melon dan semangka dengan hidroponik. Hidroponik yaitu sistem budidaya pada pertanian tanpa menggunakan tanah liat sebagai bahan menanam. Hidroponik menggunakan air yang bercampur 
larutan nutrient sebagai bahan untuk menanam (Munjidah et al., 2018). Tanaman adalah tumbuh-tumbuhan yang biasa ditanam dan dipelihara (Javandira, Purnomo, \& Rosyidah, 2018). Hidroponik sistem terapung non sirkulasi sudah berhasil diaplikasikan pada tanaman sayur (Maghfoer, Moch. Dawam; Wardiyati, Tatik; Purnomo, 2007). Kini buah melon dan semangka dapat dibentuk kotak (Purnomo, Agung; Rosyidah, 2010).

\section{KESIMPULAN}

Tips untuk memulai wirausaha pertanian agribisnis di era revolusi industri 4.0 yaitu merencanakan dokumentasi, baca, perawatan diri, catatan, tanah tepat, dan pemasaran online.

\section{REFERENCES}

Ekong, U. (2019). 7 Tips for Investing in an Agro Business. Retrieved December 22, 2019, from https://blog.farmcrowdy.com/investing-in-agrobusiness $/ \% 0 \mathrm{~A}$

Hammerich, T. (2018). 10 Tips For Getting Started in Farming. Retrieved December 21, 2019, from https://futureofag.com/10-tips-for-getting-startedin-farming-b410520a6f50

Javandira, C., Purnomo, A., \& Rosyidah, E. (2018). Kamus Pertanian. Sidoarjo: UNUSIDA Press.

Landau, C. (2019). How to Start a Farm: Your Complete Guide to Success. Retrieved December 20, 2019, from https://articles.bplans.com/how-to-starta-farm-and-how-to-start-farming/

Maghfoer, Moch. Dawam; Wardiyati, Tatik; Purnomo, A. (2007). Pengaturan Jarak Panel dengan Permukaan Media pada Teknik Hidroponik Sistem Terapung Tanaman Melon. Agrivita, 29(Khusus), 388-396.

McLean, R. (2019). Top Ten Agriculture Business Tips for Farmers. Retrieved December 20, 2019, from https://www.thebusinessbarn.co.uk/rural-businessideas-and-inspiration/rural-business-discussion-topics/top-ten-business-tipsfor-farmers/

Munjidah, A., Nahdiyah, K., Maula, I., Asitah, N., Yuniarti, D., Sholichah, S. A., ... Achmadi, A. K. (2018). Hidroponik: 5 Premis Rekognisi Bagi Pemula. https://osf.io/preprints/inarxiv/hwnvr/

Purnomo, Agung; Rosyidah, E. (2010). Rumah Kotak Tumbuh bagi Keluarga Semangka. In 102 Inovasi Indonesia (pp. 58-59). Jakarta: Business Innovation Center.

Purnomo, A., Putri, R. A., \& Rosyidah, E. (2017). Kamus Manajemen Sumber Daya Manusia. Sidoarjo: UNUSIDA Press.

Setyawati, I., Purnomo, A., Irawan, D. E., Tamyiz, M., \& Sutiksno, D. U. (2018). A Visual Trend of Literature on Ecopreneurship Research Overviewed within The Last two Decades. Journal of Entrepreneurship Education, 21(4), 1-7. Retrieved from https://www.abacademies.org/articles/a-visual-trend-ofliterature-on-ecopreneurship-research-overviewed-within-the-last-twodecades-7468.html 
Weaver, L. (2019). 5 Tips for Starting a New Ag Business. Retrieved December 19, 2019, from https://www.farmcrediteast.com/knowledgeexchange/Blog/todays-harvest/5-tips-for-starting-a-new-ag-business

Zikri, M., Sumartono, E., Novanda, R. R., Parwito, P., Purnomo, A., Busro, B., \& Supriyono. (2018). Ethnobotany of Medical Plants by Rejang Selupu Ethnic. Journal of Physics: Conference Series, 1114(1), 012130.

https://doi.org/10.1088/1742-6596/1114/1/012130 